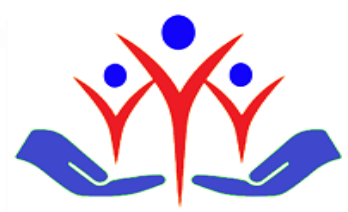

\title{
Delayed time of atrial conduction in children with Familial Mediterranean Fever
}

Ailevi Akdeniz Ateşi tanılı çocuklarda gecikmiş atrial ileti zamanı

\author{
Fatih Battal ${ }^{\mathrm{a}}$, Fatih Koksal Binnetoglu ${ }^{\mathrm{b}}$, Hakan Aylanc ${ }^{\mathrm{a}}$, Sule Yildirim $^{\mathrm{a}}$, Nazan Kaymaz $^{\mathrm{a}}$, \\ Ozturk Ozdemir ${ }^{\mathrm{c}}$ \\ a Department of Pediatrics, Faculty of Medicine, Canakkale Onsekiz Mart University, Canakkale, Turkey \\ b Department of Pediatric Cardiology, Faculty of Medicine, Canakkale Onsekiz Mart University, Canakkale, Turkey \\ c Department of Medical Genetics, Faculty of Medicine, Canakkale Onsekiz Mart University, Canakkale, Turkey
}

\begin{abstract}
Introduction: Familial Mediterranean Fever (FMF) is a disease with recurrent fever, characterized by painful, noninfectious inflammation of the serous membranes. It mostly affects Armenians, Turks, Arabs and Jews. Prolonged inflammation in FMF may lead to atrial fibrosis which can cause the deterioration of atrial conduction time and refractory periods of atrial myocardium.

In the present study we aimed to assess atrial conduction time in children with FMF.

Methods: The study included 36, children diagnosed with FMF(17 males/19 females, 13 (7-15) years) and 20 control(7 males/13 females, 11 (916) years) cases in our Pediatric Outpatient Clinic between October 2015 and October 2016. Tissue Doppler Echocardiography (TDE) measurements of intra-and interatrial electromechanical delay were done. P wave dispersion (Pdisp) was calculated from the 12-lead electrocardiogram.

Results: Inter-atrial (Lateral PA- Tricuspid PA) and Intra-left (Lateral PA-Septal PA) atrial electromechanical delay were significantly longer in FMF patients ( $\mathrm{P}<0.001$,respectively). (PA: the time range between the beginning of the $\mathrm{P}$ wave in the surface electrocardiogram and the beginning of the tissue Doppler late diastolic wave A). Also, P-wave dispersion (Pdisp) were significantly higher in FMF patients

$(\mathrm{p}=0.002)$.

Conclusions: This study shows that atrial electromechanical delay and Pdisp are prolonged in children with FMF. We recommend that atrial conduction time be measured for children diagnosed with FMF.

Keywords: Child, familial mediterranean fever, electrocardiography, electromechanical delay.
\end{abstract}

$\ddot{O} z$

Giriş: FMF seröz zarların ağrılı inflamasyonu ile karakterize tekrarlayan ateşin eşlik ettiği genetik bir hastalıktır. Çoğunlukla Ermeniler, Türkler, Araplar ve Yahudiler etkilenir. Ailesel Akdeniz Ateşinde uzun süreli inflamasyon atriyal iletim süresinin bozulmasına ve atriyal fibrozise yol açabilir. Bu çalışmada Ailesel Akdeniz Ateş olan çocuklarda atriyal iletim süresini değerlendirmeyi amaçladık.

Yöntem: Çalışmaya Ekim 2015-Ekim 2016 tarihleri arasında Çocuk Sağlı̆̆ı ve Hastalıkları Polikliniğimizde 36 FMF (17 erkek / 19 kız) tanılı hasta ile 20 kontrol (7 erkek / 13 kız) olgusu dahil edildi. Doku Doppler Ekokardiyografi ve interatriyal elektromekanik gecikme ölçümleri yapıldı. $\mathrm{P}$ dalga dispersiyonu (pdisp), 12 derivasyonlu elektrokardiyogramdan hesaplandi.

Bulgular: FMF hastalarında inter-atriyal (Lateral PA- Trikuspid PA) ve intra-left (Lateral PA-Septal PA) atriyal elektromekanik gecikme anlamlı olarak daha uzundu $(\mathrm{P}<0,001)$. (PA: yüzey elektrokardiyogramında $\mathrm{P}$ dalgasının başlangıcı ile Doku Doppler geç diyastolik dalga A'nın başlangıcı arasındaki zaman aralığı). Ayrıca FMF hastalarında P dalga dispersiyonu (Pdisp) anlamlı olarak daha yüksekti $(\mathrm{p}=0,002)$.

Sonuç: Bu çalışma FMF'li çocuklarda atriyal elektromekanik gecikme ve Pdisp'nun uzadığını göstermektedir. FMF teşhisi ile takip edilen çocukların atrial ileti sürelerinin ölçülmesini öneriyoruz.

Anahtar Kelimeler: Çocuk, ailesel akdeniz ateşi, elektrokardiyografi, elektromekanik gecikme

\begin{tabular}{|c|c|c|c|c|}
\hline Received & Accepted & Published Online & Corresponding Author & E-mail \\
\hline June 15, 2020 & February 24, 2021 & May 5, 2021 & Fatih Battal, M.D. & battalfatih@ @otmail.com \\
\hline Correspondence & $\begin{array}{l}\text { Dr. Fatih Battal, Canakkale Onsekiz Mart University Faculty of Medicine Hospital Barbaros District. } \\
\text { Terzioglu Campus Canakkale }\end{array}$ \\
\hline
\end{tabular}




\section{Introduction}

Familiar Mediterranean Fever (FMF) is an illness of persistent fever, characterized by painful, non-infectious inflammation of the serous membrane and the growth of amyloidosis[1,2]. It primarily affects Armenians, Turks, Arabs and Jews[3]. FMF is thought to be an autosomal recessive disease caused by mutations in the Mediterranean Fever gene (MEFV) that encodes 781 amino acid proteins called pyrin or marenostrin or TRIM20[4,5]. The mutation of the MEFV gene activates the development of IL-1 and causes apoptosis and inflammatory attacks. The diagnosis of FMF is mainly focused on clinical results[6]. Colchicine is the main method of therapy for FMF patients. Cardiovascular intervention is one of the most significant complications of FMF[7]. Prolonged inflammation in FMF, particularly untreated or refractory cases, appears to develop amyloidosis. This may contribute to atrial fibrosis and degradation of atrial conduction time and refractory duration of atrial myocardium[7-9]. Atrial arrhythmias can be caused by electromechanical and electrophysiological anomalies of the atrium, such as increased atrial electromechanical delay (AED) and increased P-wave dispersion (Pdisp)[10]. For this cause, a more reliable measurement of AED with Tissue Doppler Echocardiography (TDE) is possible with a high temporal resolution[11,12]. Increased AED and Pdisp were seen in adult FMF patients in previous trials [13]. In this study, we aimed to evaluate AED and Pdisp in children with FMF.

\section{Methods}

\section{Study population}

A total of 36 consecutive newly diagnosed FMF children (17 male, 19 female) who were diagnosed according to the Tell-Hashomer criteria [14] were included in this study and 20 healthy volunteers ( 7 male, 13 female) were selected from children admitted to the hospital due to murmur and diagnosed with innocent murmur after echocardiographic examination (Figure-1). Patients and healthy subjects with history of arterial hypertension, congenital and acquired heart disease, left ventricular wall motion abnormality, primary cardiomyopathy, arrhythmia, diabetes mellitus, amyloidosis and biochemical and hematological abnormality, hepatic and renal disorders were excluded from the study. All the subjects were afebrile and were in sinus rhythm and none of them were taking medications known to affect electrocardiography or heart rate. All patients were receiving continuous treatment with colchicine at appropriate doses to prevent attacks (1-2 mg/day in all patients). After we obtained the permission of the institution, parents were informed about the purpose of the study and the consent forms were signed.

\section{Ethical Approval}

Ethics committee approval was received from the Clinical Research Ethics Committee of Canakkale Onsekiz Mart University on 17.09.2015 and was numbered 2011-KAEK-27 / 2015-100.

\section{Anthropometric Measurement}

Body weight measurements were performed using 100 gram weight-sensitive scale. Height measurements were performed with standard stadiometer sensitive to 0.1 centimeters (Seca 703, accurate to 100g, Seca GmBH\&Co Kg; Hamburg, Germany). Anthropometric measurements were performed and recorded by the same person.

\section{Blood Pressure}

Subjects were rested for at least 5 minutes before their blood pressure was measured. The measurements considered the appropriate body size and were made with a mercury-gravity manometer.

\section{Echocardiographic Examination}

Using a 3-MHz probe that uses the Vivid 5 (General Electric, Horten, Norway) echocardiography device to monitor DII lead, the same pediatric cardiologist performed echocardiographic recordings on a patient with a backup and/or left wing position. All patients were evaluated by including M-mode, two-dimensional, color, continuous, and pulse wave doppler examination. Every participants were tested for posterior wall thickness, left ventricular (LV), LV internal diameters, interventricular septal wall thickness. The scale of the cardiac chamber and the systolic and diastolic functions of the LV were commented on in compliance with the recommendations of the American Society of Echocardiography. Doppler photos, early left ventricular filling wave (E), upper left ventricular filling wave (A), isovolumic relaxation time and deceleration time (DT) were included in the measurements. TDE displayed peak systolic ( $\left.\mathrm{S}^{\prime}\right)$, early diastolic (E') and late diastolic (A') myocardial velocity in the lateral mitral annulus.

\section{Measurements of Atrial Electromechanical Delay}

In our research, PA corresponds to the time period between the beginning of the $\mathrm{P}$ wave in the surface electrocardiogram and the beginning of the Doppler late diastolic wave tissue (A). In addition, inter-atrial electromechanical delay refers to the difference between lateral and tricuspid PA (lateral PA-tricuspid PA) and intra-atrial right electromechanical delay refers to the difference between septal PA and tricuspid PA (septal PAtricuspid PA), intra-atrial left electromechanical delay refers to the difference between lateral PA and septal PA (lateral PA- septal PA). (Figure 2) $[15,16]$. Lateral mitral ring (lateral PA), septal mitral ring (septal PA) and right ventricular tricuspid ring (tricuspid PA) were used for measurements. (Figure-3). Three readings were made for each parameter and averaged.

\section{Measurement of P Wave Dispersion}

The same pediatric cardiologist was used to measure ECG findings. The duration of the P-wave was measured in milliseconds. The starting point of the $\mathrm{P}$ wave was determined as the starting point of the first positive wave moving upwardly visible from the isoelectric line or the first downwardly moving negative wave visible from the isoelectric line. The return point of the wave to the isoelectric line was determined as the end of the $\mathrm{P}$ wave. $\mathrm{P}$ wave dispersion (Pdisp) was calculated after measuring the longest (Pmax) and shortest (Pmin) P wave in any lead of 12-lead ECG $($ Pdisp = Pmax-Pmin $)[17,18]$. 


\section{Statistical Analysis}

SPSS software version 20.0 (SPSS Inc., Chicago, IL) was used for statistical analyses. Shapiro-Wilk test was used to determine whether continuous variables exhibited normal deviation and compared with the independent sample t-test. The Mann-Whitney $\mathrm{U}$ test was used when the sample of some of the continuous variables did not show normal distribution. Spearman correlation analysis was used to show the relationships between continuous variables. Statistical significance was accepted as $\mathrm{p}<0.05$.

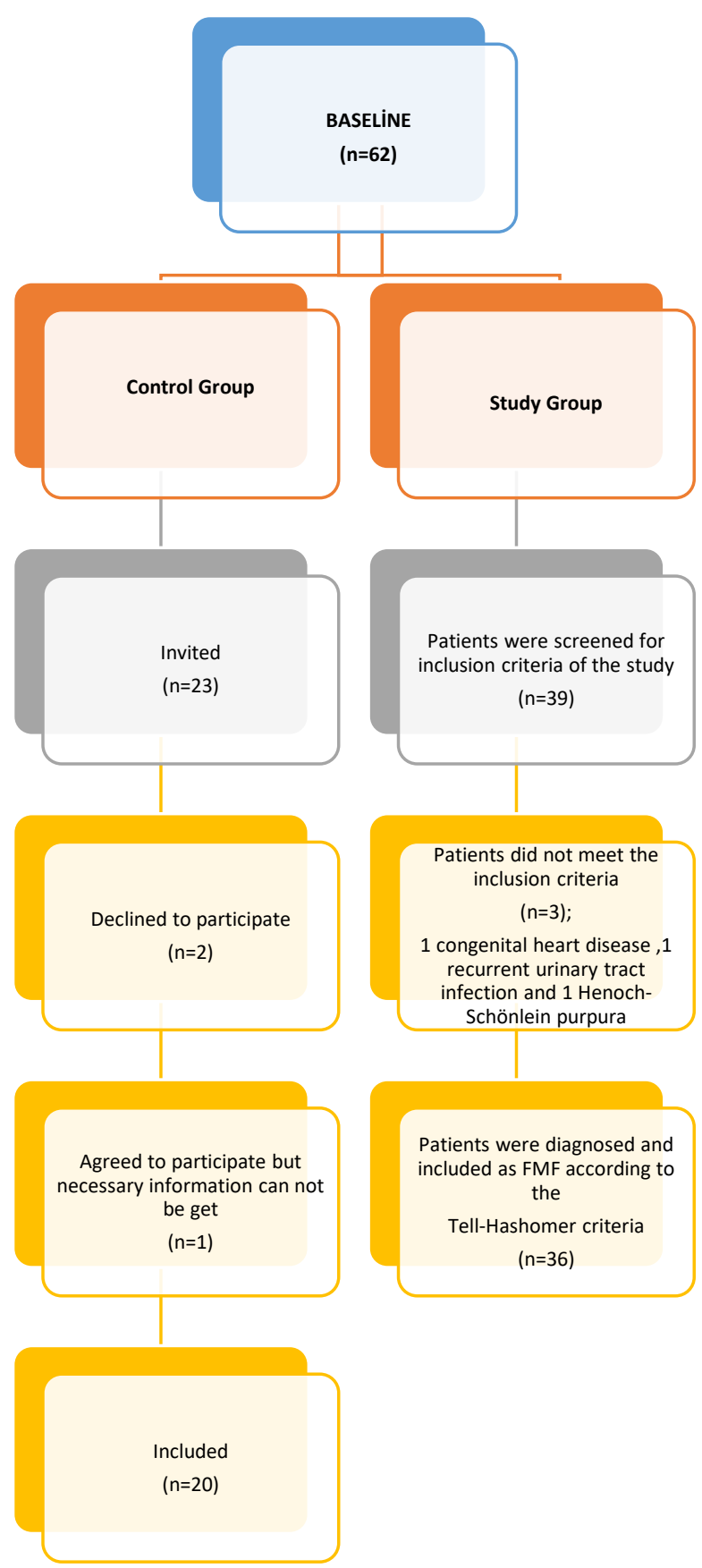

Figure 1. Flow-chart of patient selection.

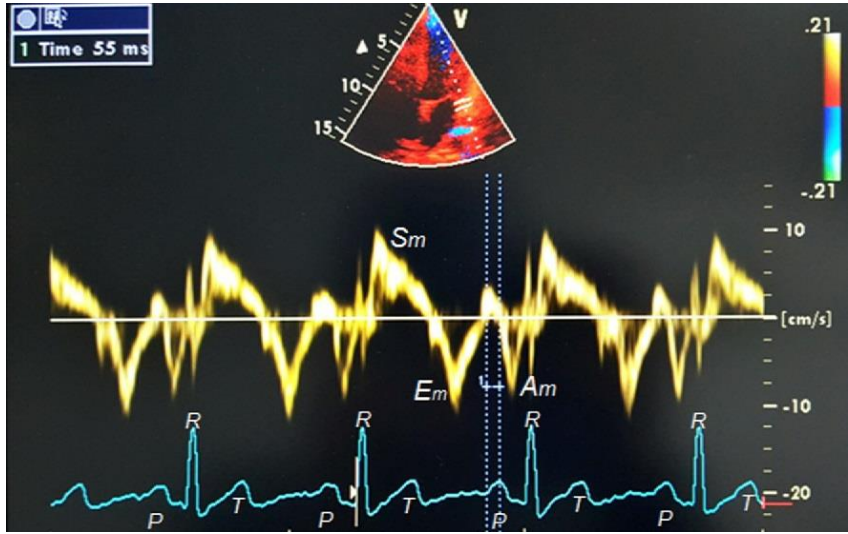

Figure 2. Measurement of time interval from the onset of $P$ wave on surface ECG to the beginning of $\mathrm{A}_{\mathrm{m}}$ wave (PA) interval with tissue Doppler echocardiography.

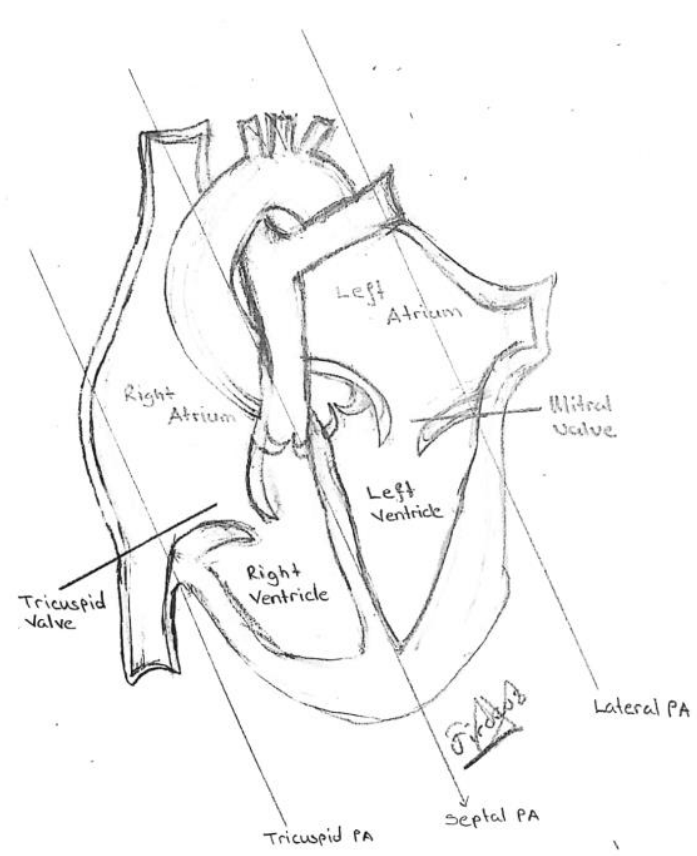

Figure 3. Schematic view of tricuspid PA, septal PA and tricuspid PA delivery times 


\section{Results}

The clinical features of the groups studied were given in Table 1. The two groups were similar regarding age, gender, and blood pressure. Comparison of atrial electromechanical delay parameters of the groups are summarized in Table-2. Lateral PA was significantly higher in children with FMF compared with controls $(\mathrm{P}<0.001)$. Septal PA, and tricuspid PA did not differ significantly between the groups $(\mathrm{p}=0.352, \mathrm{p}=0,088$ respectively). Furthermore, intra-atrial left and inter-atrial electromechanical delay were also prolonged in patients with FMF compared with controls ( $<<0.001$ respectively). Electrocardiographic findings, two-dimensional echocardiography and Tissue Doppler findings of the groups are summarized in Table 3. P-wave measurements are given in Table 4. Maximum P-wave duration (Pmax) and P dispersion (Pdisp) were significantly higher in FMF patients compared with controls $(\mathrm{P}<0.001, \mathrm{P}=0.002$, respectively).

Table 1. Clinical characteristics of study and control groups

\begin{tabular}{|l|c|c|c|}
\hline & Study Group (n:36) & Control Group (n:20) & P value \\
\hline *Age, years (median) & $11.58 \pm 2.95$ & $11.45 \pm 1.73$ & 0.832 \\
\hline Male & 17 & 7 & $0.413 *$ \\
& 19 & 13 & 0.087 \\
\hline Hender & $149.56 \pm 17.77$ & $142.80 \pm 11.20$ & 0.161 \\
\hline Weight, $\mathrm{cm}$ & $46.36 \pm 15.54$ & $41.80 \pm 8.45$ & 0.580 \\
\hline BMI $(\mathrm{kg} / \mathrm{m} 2)$ & $19.97 \pm 3.09$ & $20.30 \pm 1.30$ & 0.074 \\
\hline *Systolic BP (mmHg) (median) & $109.22 \pm 11.52$ & $103.70 \pm 9.52$ & 0.877 \\
\hline *Diastolic BP (mmHg)(median) & $64.30 \pm 9.54$ & $64.7 \pm 8.18$ & \\
\hline
\end{tabular}

Significant $\mathrm{P}$ value $<0,05$. Normally distributed data were presented as mean $\pm \mathrm{SD}$ and statistical evaluation t-test was used. *Which are not normally distributed Such data were presented as median \pm interquartile range and statistical evaluation Mann-Whitney test was used. *Fisher's Exact Test BMI = Body Mass Index; BP $=$ Blood Pressure.

Table 2. Comparison of the atrial electromechanically delay parameters of study and control groups

\begin{tabular}{|l|c|c|c|c|c|c|}
\hline & Study Group (n:36) & Control Group (n:20) & P value & Z value & T value & 95\% CI \\
\hline Lateral PA (ms) & $56.14 \pm 7.25$ & $44.85 \pm 2.66$ & $<0.001$ & & 8.379 & $8.58-14.00$ \\
\hline Septal PA (ms) & $39.54 \pm 5.29$ & $37.65 \pm 4.58$ & $0.352^{*}$ & $-0.930^{*}$ & & \\
\hline Tricuspid PA (ms) & $27.51 \pm 3.67$ & $25.79 \pm 3.31$ & 0.088 & & 1.737 & $-2.27-3.70$ \\
\hline Intra-atrial left ED (ms) & $16.60 \pm 5.46$ & $7.20 \pm 3.48$ & $<0.001$ & & 7.850 & $7.00-11.80$ \\
\hline Inter-atrial ED (ms) & $28.63 \pm 6.72$ & $19.06 \pm 3.83$ & $<0.001$ & & 6.784 & $6.29-12.85$ \\
\hline Intra-atrial right ED (ms) & $12.03 \pm 3.93$ & $11.86 \pm 4.54$ & 0.883 & & 0.147 & $-2.15-2.50$ \\
\hline
\end{tabular}

Student $\mathrm{T}$ test was used. Significant $\mathrm{P}$ value $<0,05$. *Data that are not normally distributed were presented as median \pm interquartile range and statistical evaluation Mann-Whitney test was used. CI: Confidence Interval ED: Electromechanical delay PA: the time range between the beginning of the P wave in the surface electrocardiogram and the beginning of the tissue Doppler late diastolic wave A). * Levene's Test for Equality of Variances

Table 3. Comparison of the research and control groups' echocardiographic and TDE parameters

\begin{tabular}{|l|c|c|c|c|c|c|}
\hline & Study Group (n:36) & Control Group (n:20) & P value & Z Value & T Value & CI 95\% \\
\hline E velocity, m/sec & $1.00 \pm 0.16$ & $0.96 \pm 0.16$ & 0.037 & 0.826 & $-0.05-0.12$ \\
\hline A velocity, m/sec & $0.54 \pm 0.11$ & $0.50 \pm 0.09$ & 0.036 & & 1.286 & $-0.02-0.09$ \\
\hline *Dec time $^{\text {E' }}$ & $148.11 \pm 29.96$ & $52.95 \pm 19.30$ & $0.572^{*}$ & $-0.565^{*}$ & & \\
\hline *A' $^{\prime}$ & $0.17 \pm 0.03$ & $0.17 \pm 0.03$ & 0.908 & & -0.116 & $-0.02-0.02$ \\
\hline LVEDD $(\mathrm{mm})$ & $0.07 \pm 0.02$ & $0.06 \pm 0.01$ & $0.438^{*}$ & $-0.775^{*}$ & & \\
\hline LVESD $(\mathrm{mm})$ & $41.75 \pm 6.58$ & $39.75 \pm 3.61$ & 0.215 & & 1.255 & $-1.20-5.19$ \\
\hline *IVSd & $26.94 \pm 4.28$ & $26.35 \pm 2.60$ & 0.575 & 0.564 & $-1.51-2.70$ \\
\hline IVSs & $6.61 \pm 1.53$ & $5.85 \pm 1.13$ & $0.056^{*}$ & $-1.909 *$ & & \\
\hline LPWd & $8.39 \pm 2.23$ & $7.25 \pm 1.37$ & 0.022 & & 2.361 & $0.17-2.10$ \\
\hline LPWs & $6.36 \pm 1.62$ & $5.65 \pm 1.26$ & 0.097 & & 1.690 & $-0.13-1.55$ \\
\hline *LVEF $(\%)$ & $10.25 \pm 2.62$ & $9.85 \pm 2.13$ & 0.563 & & 0.583 & $-0.97-1.77$ \\
\hline *LVFS $(\%)$ & $65.16 \pm 4.59$ & $63.60 \pm 2.44$ & $0.242^{*}$ & $-1.170^{*}$ & & \\
\hline
\end{tabular}

Value of significant $\mathrm{P}<0,05$. The normally distributed data was presented as mean $\pm \mathrm{SD}$ and the t-test statistical evaluation was used. *Data not normally distributed were presented as a median \pm interquartile range and the Mann-Whitney test was used for statistical assessment. TDE $=$ Tissue Doppler echocardiography; $\mathbf{E}=$ Peak early left ventricular filling wave; $\mathbf{A}=$ Peak late left ventricular filling wave; Dec Time= Deceleration time; $\mathbf{E}^{\prime}=$ Peak early diastolic velocity; $\mathbf{A}^{\prime}=$ Peak late diastolic velocity; LVEDD= Left ventricular end-diastolic dimension; LVESD= Left ventricular end-systolic dimension; IVSDd= Interventricular septum diastolic thickness; IVSs= Interventricular septum systolic thickness; LPWd= Left ventricular posterior wall diastolic thickness; LPWs= Left ventricular posterior Wall systolic thickness; $\mathbf{L V E F}=$ Left ventricular ejection fraction; $\mathbf{L V F S}=$ Left ventricular shortening fract 
Table 4. $\mathrm{P}$ wave dispersion parameters for study and control groups

\begin{tabular}{|l|c|c|c|}
\hline & Study Group (n:36) & Control Group (n:20) & P value \\
\hline P $\max$ & $0.14( \pm 0.012)$ & $0.12( \pm 0.015)$ & $<0.001$ \\
\hline P min & $0.08( \pm 0.006)$ & $0.07( \pm 0.011)$ & 0.002 \\
\hline P disp & $0.066( \pm 0.014)$ & $0.049( \pm 0.019)$ & 0.002 \\
\hline
\end{tabular}

Significant value of $\mathrm{P}<0,05$. Data distributed differently from normal were presented as a median \pm interquartile range and the Mann-Whitney test was used for statistical evaluation. Pmax=maximum P-wave duration, Pmin= minimum P-wave duration, Pdisp= P-wave dispersion

\section{Discussion}

This research revealed an improvement in intra-atrial left and inter-atrial electromechanical delay in children with FMF. In comparison, Pdisp was higher in children with FMF relative to their stable peers. Data suggesting the impact of inflammation on atrial fibrillation is present in the literature[19]. Some of them investigate the relationship between systemic inflammation and atrial retardation. One research indicated that excessive atrial electromechanical latency in psoriasis subjects is due to inflammation[20]. Most FMF patients undergo their first episode in childhood. It is well known that a number of chronic inflammatory disorders, such as juvenile idiopathic arthritis, can cause clinical and subclinical cardiovascular complications[21,22]. Unfortunately, there are few research on cardiovascular risks of FMF in children.

Various manifestations have been identified in a recent review of the literature on cardiac manifestations in FMF patients. This involved pulmonary hypertension, valve disorders, cardiomyopathies, pericarditis, coronary heart disease and subclinical atherosclerosis. However, the effects in children were also not specified in their review[23]. However, there are few research exploring the impact to children. [23]. Chronic inflammation may lead to fibrosis in atrial and ventricular myocardium which can cause electrical inhomogeneity, conduction and repolarization abnormalities. While FMF is a disorder marked by elevated inflammatory activity, there is no clinical evidence of an increase in atrial inflammation and risk of atrial fibrillation in these cases [13]. Recurrent inflammatory attacks in children can cause all kinds of rhythm problems. If the inflammatory process is controlled at an early age, rhythm disorders may be prevented at a later time. Aslan et al. reported that Pdisp value was significantly higher in patients with FMF than control subjects [24]. Systolic and diastolic cardiac functions may be affected by chronic rheumatic diseases with effects such as abnormal myocardial collagen accumulation, myocardial infarction, focal inflammation, vasculitis, myocarditis, arthritis and amyloidosis. [25]. In particular, diastolic LV dysfunction is relatively common in patients with chronic inflammation. The study reported that the right ventricular diastolic function indices in patients with FMF deteriorated in childhood, while the left ventricular function was similar. [19]. As a result, impaired right ventricular diastolic function may be an early indication of cardiac involvement in children with FMF. Ceylan et al. found that longitudinal global strain, radial global strain, and strain rates were statistically lower in FMF patients in a study evaluating the early changes in systolic and diastolic functions using TDE and strain and strain rate echocardiography in patients with FMF without any cardiac symptoms [26].

\section{Limitations}

Arhythmic episodes or complications cannot be followed in a prospective way. Prospective and long-term follow-up trials are required to establish whether Pdisp prolongation and atrial electromechanical delay predict the occurrence of atrial arrhythmia in FMF patients.. Invasive electrophysiological methods have still not been employed. Another limitation of our research was that it was conducted with a single cardiologist for children. We could therefore be unable to quantify the importance of interobserver uncertainty. In children with FMF, our research has the highest number of cases investigating atrial conduction time.. This is our research's strength..

\section{Conclusion}

Atrial delay can be an early indication of atrial involvement in children with FMF. Since FMF patients experience childhood attacks, early diagnosis and treatment of FMF is very important. Subclinical cardiovascular complications of FMF may be detected in childhood. Patients with atrial delay should be monitored by annual TDE and ECG. These patients can also be monitored 24 hours a day, if necessary. Our analysis will be a reference for subsequent large-scale studies in this area. Prospective studies with reduced limitation may increase the level of evidence from our findings. Prospective and comprehensive studies that will include a larger number of patients are needed to conclude our study with definitive results.

Conflict of interest: None.

Financial support: None

Prior publication: The Turkish abstract of the manuscript was presented in 14th Uludag Pediatrics Winter Congress, in Bursa at March 2018. Abstract supplement was not published in any journal.

Acknowledgements The authors thank our 10-year-old patient, Firdevs, who schematized the pathways of the heart (Figure-3).

\begin{tabular}{|r|l|l|}
\hline \multicolumn{2}{|c|}{ Author Contributions } & \multicolumn{1}{c|}{ Author Initials } \\
\hline SCD & Study Conception and Design & FB, FKB \\
\hline AD & Acquisition of Data & FB, FKB, OO \\
\hline AID & Analysis and Interpretation of Data & HA, NK, SO \\
\hline DM & Drafting of Manuscript & FB, FKB \\
\hline CR & Critical Revision & HA, NK, SO \\
\hline
\end{tabular}




\section{References}

1. McDermott MF, Aksentijevich I, Galon J, McDermott EM, Ogunkolade BW, Centola M,.et al. Germ line mutations in the extracellular domains of the $55 \mathrm{kDa}$ TNF receptor,TNFR1,define a family of dominantly inherited autoinflammatory syndromes. Cell. 1999;97 (1):1334. https://doi.org/10.1016/s0092-8674(00)80721-7

2. Brydges S, Kastner DL. The systemic autoinflammatory diseases: inborn errors of the innate immune system. Curr Top Microbiol Immunol. 2006;305:127-60. https://doi.org/10.1007/3-540-29714-6_7

3. Manukyan G, Aminov R. Update on Pyrin Functions and Mechanisms of Familial Mediterranean Fever. Front Microbiol. 2006;31(7):456. https://doi.org/10.3389/fmicb.2016.00456

4. The French FMF Consortium. A candidate gene for familial mediterranean fever. Nat Genet. 1997;17(1):25-31. https://doi.org/10.1038/ng0997-25

5. The International FMF Consortium. Ancient missense mutations in a new member of the RoRet gene family are likely to cause familial Mediterranean fever. The International FMF Consortium. Cell 1997;90 (4):797-807. https://doi.org/10.1016/s0092-8674(00)80539$\underline{5}$

6. Soriano A, Manna R. Familial Mediterranean fever: New Phenotypes. Autoimmun Rev 2002;12(1):31-7. https://doi.org/10.1016/j.autrev.2012.07.019

7. Canpolat U, Dural M, Aytemir K, Akdoğan A, Kaya EB, Sahiner Let al. Evaluation of various cardiac autonomic indices in patients with familial Mediterranean fever on colchicine treatment. Auton Neurosci 2012;(1)167:70-4. https://doi.org/10.1016/j.autneu.2011.11.001

8. Gale A, Levin ME. Pericarditis And Auricular Fibrillation. Occurrence in Familial Mediterranean Fever.Arch Intern Med 1963;112(2) 23441. https://doi.org/10.1001/archinte.1963.03860020132018

9. Koca B, Kasapçopur O, Bakari S, Sönmez E, Oztunç F, Eroğlu AG et al. QT dispersion and cardiac involvement in children with Familial Mediterranean fever.Cardiol Young 2012;22(4):404-9. https://doi.org/10.1017/s1047951111001867

10. Daubert JC, Pavin D, Jauvert G, Mabo P. Intra and interatrial conduction delay: implications for cardiac pacing. Pacing Clin Electrophysiol 2004;27:(4):507-5. https://doi.org/10.1111/j.1540-8159.2004.00473.X

11. Cui QQ, Zhang W, Wang H, Sun X, Wang R, Yang HY et al. Assessment of atrial electromechanical coupling and influential factors in nonrheumatic paroxysmal atrial fibrillation. Clin Cardiol 2008;31(2):74-8. https://doi.org/10.1002/clc.20162

12. Omi W, Nagai H, Takamura M, Okura S, Okajima M, Furusho H et al. Doppler tissue analysis of atrial electromechanical coupling in paroxysmal atrial fibrillation. J Am Soc Echocardiogr 2005;18(1):39-4. https://doi.org/10.1016/j.echo.2004.08.029

13. Acar G, Akcay A, Sayarlioglu M, Sokmen A, Sokmen G, Koroglu S et al. Assessment of atrial conduction time in patients with familial Mediterranean fever. Pacing Clin Electrophysiol 2009;32(3):308-13. https://doi.org/10.1111/j.1540-8159.2008.02237.x

14. Livneh A, Langevitz P, Zemer D, Zaks N, Kees S, Lidar T et al. Criteria for the diagnosis of familial Mediterranean fever. Arthritis Rheum 1997;40(10):1879-5. https://doi.org/10.1002/art.1780401023

15. Deniz A, Sahiner L, Aytemir K, Kaya B, Kabakci G, Tokgozoglu L, et al. Tissue Doppler echocardiography can be a useful technique to evaluate atrial conduction time. Cardiol J 2012;19(5):487-3. https://doi.org/10.5603/cj.2012.0089

16. Ozer N, Yavuz B, Can I, Atalar E, Aksoyek S, Ovunç K, et al. Doppler tissue evaluation of intra-atrial and interatrial electromechanical delay and comparison with P-wave dispersion in patients with mitral stenosis. J Am Soc Echocardiogr 2005;18(9):945-8. https://doi.org/10.1016/j.echo.2005.01.015

17. Waggoner AD, Adyanthaya AV, Quinones MA, Alexander JK. Left atrial enlargement. Echocardiographic assessment of electrocardiographic criteria. Circulation 1976;54:553-7. https://doi.org/10.1161/01.cir.54.4.553

18. Dilaveris PE, Gialafos EJ, Sideris SK, Theopistou AM, Andrikopoulos GK, Kyriakidis M, et al. Simple electrocardiographic markers for the prediction of paroxysmal idiopathic atrial fibrillation. Am Heart J 1998;135(5):733-8. https://doi.org/10.1016/s0002-8703(98)70030-4

19. Boos CJ, Anderson RA, Lip GYH. Is atrial fibrillation an inflammatory disorder? Eur Heart J 2006;27(2):136-39. https://doi.org/10.1093/eurheartj/ehi645

20. Yildiz A, Ucmak D, Oylumlu M, Akkurt MZ, Yuksel M, Akil MA et al. Assessment of Atrial Electromechanical Delay and P-Wave Dispersion in Patients with Psoriasis Echocardiography. 2014;31(9):1071-6 https://doi.org/10.1111/echo.12530

21. Ozdemir O, Agras PI, Aydın Y, Abacı A, Hızlı S, Akkuş HI, et al. Assessment of cardiac functions using tissue Doppler imaging in children with familial Mediterranean fever. Cardiol Young 2012;22(2):188-3. https://doi.org/10.1017/s1047951111001168

22. Yılmaz O, Ceylan O, Orün UA, Ozgur S, Karademir S, Doğan V, et al. Assessment of left ventricular functions with tissue Doppler, strain and strain rate echocardiography in children with juvenile idiopathic arthritis: An observational study. Anatol J Cardiol 2012; 12: 339-46 https://doi.org/10.5152/akd.2012.098

23. Alsarah A, Alsara O, Laird-Fick HS. Cardiac manifestations of Familial Mediterranean fever. Avicenna J Med 2017;7(4):158-3. https://dx.doi.org/10.4103\%2Fajm.AJM_78_17

24. Arslan D, Oran B, Yazilitas F, Peru H, Cimen D, Vatansev H. P-wave duration and dispersion in children with uncomplicated familial Mediterranean fever. Mod Rheumatol 2013;23(6):1166-1. https://doi.org/10.1007/s10165-012-0815-6

25. Rexhepaj N, Bajraktari G, Berisha I, Beqiri A, Shatri F, Hima F, et al. Left and right ventricular diastolic functions in patients with rheumatoid arthritis without clinically evident cardiovascular disease. Int J Clin Pract 2006;60(6):683-8. https://doi.org/10.1111/j.1368$\underline{5031.2006 .00746 . x}$

26. Ceylan Ö, Özgür S, Örün UA, Doğan V, Yılmaz O, Keskin M, et al. Assessment of left ventricular functions with tissue Doppler, strain, and strain rate echocardiography in patients with familial Mediterranean fever. Anatol J Cardiol 2015;15(8):663-8. https://doi.org/10.5152/akd.2014.5544 